\title{
PENGELOMPOKAN JUMLAH PENDUDUK BERDASARKAN KATEGORI USIA DENGAN METODE K-MEANS
}

\author{
Sahat Sonang S. ${ }^{1}$, Arifin Tua Purba ${ }^{2}$, Ferri Ojak Imanuel Pardede ${ }^{3}$ \\ 1,2,3 Teknik Komputer, Politeknik Bisnis Indonesia \\ Email : sahatsonangstg@gmail.com¹, arifintuaprb20@gmail.com², ferri_pardede@yahoo.com³
}

\begin{abstract}
Control of population is one of the tasks of the government in Indonesia. The increase and movement of population in each region makes a certain area to defeat changes in population surging, and this can affect the economic level of the area. This study aims to process the population of Pematangsiantar City in 2018 which is divided into age groups, namely: Toddlers, Young Children, Early Adolescents, Late Adolescents, Early Adolescents, Late Adulthood, Early Adulthood, Elderly, Late Elderly, and Upper Seniors. Data processing is done by using K-Means method clustering in accordance with the population of Pematangsiantar City per district. With this grouping, we can see that the number of population in each sub-district is based on each age group so that we can implement programs that are more appropriate in improving human resources.
\end{abstract}

Keywords: Clustering, Number of Population, K-Means.

\section{PENDAHULUAN}

Pertambahan jumlah penduduk di suatu kota ataupun kabupaten jika tidak diselesaikan dengan baik dan sistematis akan mengakibatkan dampak-dampak yang buruk seperti halnya banyaknya pengangguran, tingkat pencemaran lingkungan yang semakin meningkat, berkurangnya lahan terbuka hijau karena dipergunakan untuk pemukiman penduduk, pertumbuhan ekonomi, dan dampak-dampak lainnya. Pertambahan jumlah penduduk juga akan mempengaruhi pertumbuhan ekonomi.

Pengolahan Jumlah penduduk dalam penelitian ini dikelompokkan berdasarkar usia, yaitu : Balita, Kanak-Kanak, Remaja Awal, Remaja Akhir, Dewasa Awal, Dewasa Akhir, Lansia Awal, Lansia Akhir, dan Manula Atas yan diperoleh data jumlah penduduk per kecamatan di Kota Pematangsiantar tahun 2018. Melalai data ini peneliti akan mengelompokkan kecamatan yang jumlah penduduk yang lebih tinggi.

Teknologi data mining merupakan salah satu alat bantu untuk penggalian data pada basis data berukuran besar dan dengan spesifikasi tingkat kerumitan yang telah banyak digunakan pada banyak domain aplikasi seperti perbankan maupun bidang telekomunikasi [1], [2].

Metode K-Means adalah salah satu metode cluster non hirarki yang bertujuan untuk membantu pengelompokkan variabel untuk dimasukkan kedalam kelas-kelas yang terletak pada hasil akhir perhitungan [3].
K-Means merupakan salah satu metode data clustering non hirarki yang berusaha mempartisi data yang ada ke dalam bentuk satu atau lebih cluster/kelompok. Metode ini mempartisi data ke dalam cluster/kelompok sehingga data yang memiliki karakteristik sama dikelompokkan ke dalam satu cluster yang sama [4].

\section{METODE PENELITIAN}

\subsection{Clustering}

Clustering adalah sebuah proses untuk mengelompokan data ke dalam beberapa cluster atau kelompok sehingga data dalam satu cluster memiliki tingkat kemiripan yang maksimum dan data antar cluster memiliki kemiripan yang minimum. Analisis cluster (Clustering) merupakan usaha untuk mengidentifikasi kelompok obyek yang mirip-mirip dan membantu menemukan pola penyebaran dan pola hubungan dalam sekumpulan data yang besar [5].

\subsection{Algoritma Klasifikasi K-Means}

Algoritma $K$-means adalah implementasi dari algoritma clustering partisional yang paling sederhana dan paling banyak digunakan. $K$-means juga menggunakan kuadrat error criterion. Algoritma ini mulai mempartisi ruang data secara acak sambil penunjukan (assignment) sampel yang ada ke dalam kluster-kluster berdasarkan kemiripan antara kluster dan sampel, sampai sebuah criterion yang convergen 
ditemukan. Syarat sebuah criterion telah ditemukan adalah ketika tidak ada lagi pemindahan sampel (reassignment) dari satu kluster ke kluster yang lain yang akan menyebabkan berkurangnya total error yang dikuadratkan (errorsquare). Algoritma ini populer digunakan karena kemudahan implementasinya, dan memiliki kecepatan yang cukup baik.

Tahapan-Tahapan dasar yang diambil oleh algoritma $K$-means adalah:

1. Tahap pertama: Tanyakan kepada pemakai algoritma $K$-means, catatancatatan yang ada akan dibuat menjadi beberapa kelompok, sebutlah sebanyak $k$ kelompok.

2. Tahap kedua: secara sembarang, pilih $k$ buah catatan (dari sekian catatan yang ada) sebagai pusat-pusat kelompok awal.
3. Tahap ketiga: untuk setiap catatan, tentukan pusat kelompok terdekatnya dan tetapkan catatan tersebut sebagai anggota dari kelompok yang terdekat pusat kelompoknya. Hitung rasio antara besaran Beetween Cluster Variation dengan Within Cluster Variation, lalu bandingkan rasio tersebut dengan rasio sebelumnya(bila sudah ada). Jika rasio tersebut membesar, maka lankutkan ke langkah keempat. Jika tidak hentikan prosesnya.

4. Tahap keempat: perbaharui pusat-pusat kelompok (berdasarkan kelompok yang didapat dari langkah ketiga) dan kembali ke langkah ketiga.

Flowchart mengenai Tahapan-Tahapan penerapan metode K-Means ditampilkan pada Gambar 1

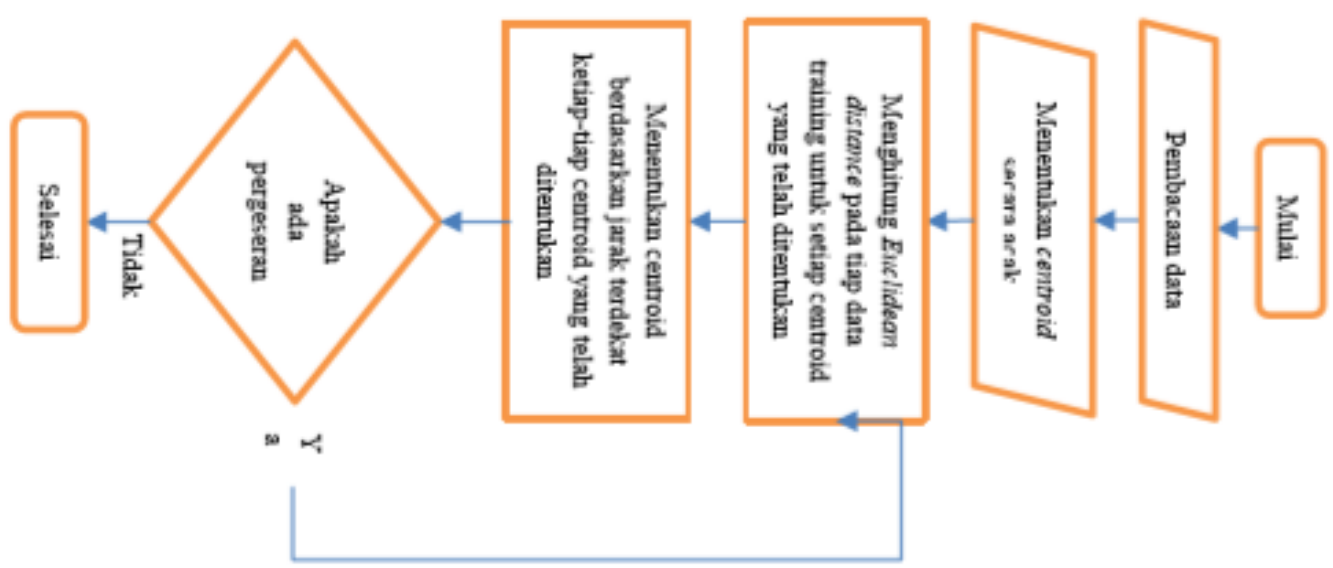

Gambar 1. Flowchart K-Means Clustering

\subsection{Kategori Usia}

Menurut Departemen Kesehatan

Republik Indonesia tahun 2009 kategri umur, yakni :

a. Masa balita usia $0-5$ tahun

b. Masa kanak-kanak usia 5-11 tahun

c. Masa remaja awal usia $12-16$ tahun

d. Masa remaja akhir usia $17-25$ tahun

e. Masa dewasa awal usia $26-35$ tahun

f. Masa dewasa akhir usia $36-45$ tahun

g. Masa lansia awal usia $46-55$ tahun h. Masa lansia akhir usia 56-65 tahun

i. Masa manula usia 65 - ke atas

\section{HASIL DAN PEMBAHASAN}

3.1. Data Pengujian

Pengelompokan data dilakukan dengan menggunakan K-Means Clustering dengan sampel data jumlah penduduk setiap kecamatan di kota Pematangsiantar yang dibagi dalam kategori umur menurut Depkes Republik Indonesia. yaitu : Balita, Kanak-Kanak, Remaja Awal, Remaja Akhir, Dewasa Awal, Dewasa Akhir, Lansia Awal, Lansia Akhir, dan Manula Atas 
Tabel 1. Data Jumlah Penduduk per Kecamatan Kota Pematangsiantar tahun 2018

\begin{tabular}{|c|c|c|c|c|c|c|c|c|c|c|}
\hline NO & Kecamatan & $\begin{array}{c}\text { Balita } \\
(0-5 \\
\text { Thn }) \\
\end{array}$ & $\begin{array}{c}\text { Kanak- } \\
\text { Kanak } \\
(5-11 \\
\text { Thn) } \\
\end{array}$ & $\begin{array}{c}\text { Remaja } \\
\text { Awal } \\
(12-16 \\
\text { Thn) } \\
\end{array}$ & $\begin{array}{c}\text { Remaja } \\
\text { Akhir } \\
(17-25 \\
\text { Thn }) \\
\end{array}$ & $\begin{array}{c}\text { Dewasa } \\
\text { Awal } \\
(26-35 \\
\text { Thn }) \\
\end{array}$ & $\begin{array}{c}\text { Dewasa } \\
\text { Akhir } \\
(36-45 \\
\text { Thn }) \\
\end{array}$ & $\begin{array}{c}\text { Lansia } \\
\text { Awal } \\
(46-55 \\
\text { Thn }) \\
\end{array}$ & $\begin{array}{c}\text { Lansia } \\
\text { Akhir } \\
(55-65 \\
\text { Thn) } \\
\end{array}$ & $\begin{array}{c}\text { Manula } \\
\text { Atas } \\
(65>= \\
\text { Thn }) \\
\end{array}$ \\
\hline 1 & $\begin{array}{l}\text { Siantar } \\
\text { Selatan }\end{array}$ & 1,334 & 1,574 & 1,637 & 3,196 & 2,205 & 2,535 & 2,346 & 1,805 & 1,378 \\
\hline 2 & \begin{tabular}{|l|} 
Siantar \\
Barat
\end{tabular} & 3,244 & 3,209 & 3,114 & 6,593 & 5,600 & 5,228 & 4,736 & 3,555 & 2,160 \\
\hline 3 & $\begin{array}{l}\text { Siantar } \\
\text { Marimbun }\end{array}$ & 1,468 & 1,583 & 1,611 & 2,820 & 1,861 & 2,061 & 2,057 & 1,388 & 890 \\
\hline 4 & \begin{tabular}{|l|l|} 
Siantar \\
Marihat
\end{tabular} & 1,741 & 1,930 & 1,969 & 3,559 & 2,396 & 2,466 & 2,328 & 1,743 & 1,125 \\
\hline 5 & \begin{tabular}{|l|l|} 
Siantar \\
Martoba
\end{tabular} & 4,378 & 4,347 & 4,021 & 7,364 & 6,221 & 5,788 & 4,545 & 2,664 & 1,481 \\
\hline 6 & \begin{tabular}{|l|} 
Siantar \\
Sitalasari
\end{tabular} & 2,717 & 2,826 & 2,625 & 5,229 & 4,106 & 4,161 & 3,594 & 2,255 & 1,246 \\
\hline 7 & $\begin{array}{l}\text { Siantar } \\
\text { Timur }\end{array}$ & 3,240 & 3,613 & 3,550 & 9,527 & 5,347 & 5,305 & 4,448 & 3,193 & 2,319 \\
\hline 8 & \begin{tabular}{|l|} 
Siantar \\
Utara
\end{tabular} & 4,599 & 4,648 & 4,485 & 9,387 & 7,094 & 6,552 & 5,776 & 3,907 & 2,502 \\
\hline
\end{tabular}

\subsection{Hasil Pelatihan}

Tahapan-tahapan algoritma klasifikasi $K$-Means untuk mengelompokkan data yang ada.

1. Tahap Pertama dari K-Means clustering adalah pemakai akan menentukan jumlak kelompok yang akan dibuat dalam pengelompakan data. Sebagai contoh dalam penyelesaian kasus ini kita akan membagi dalam 3 kelompok atau $\mathrm{k}=3$.

2. Tahap Kedua. secara sembarang memilih 3 record dari data yang akan kita uji sebagai pusat data awal setiap kelompok. misalnya

a. Record ke-1 sebagai Cluster 1 sehingga $C 1=\{1.334, \quad 1.574$, $1.637,3.196,2.205,2.535$, $2.346,1.805,1.378\}$

b. Record ke-3 sebagai Cluster 2 sehingga $C 2=\{1.468, \quad 1.583$, $1.611,2.820,1.861,2.061$, $2.057,1.388,890\}$

c. Record ke-5 sebagai Cluster 3 sehingga $C 3=\{4.378,4.347$, $4.021, \quad 7.364, \quad 6.221, \quad 5.788$, $4.545,2.664,1.481\}$

3. Tahap ketiga. setiap record akan ditentukan pusat kelompok terdekatnya. Record tersebut akan ditetapkan sebagai kelompok yang terdekat pusat kelompoknya. Hitung jarak setiap data yang ada terhadap setiap pusat cluster dengan persamaan berikut:

$\mathrm{D}(\mathrm{x} . \mathrm{y})=\sqrt{\sum_{i=1}^{m}\left(x_{i}-y_{i}\right)^{2}}$

Cluster 1 (C1):

$D_{11}$

$=\sqrt{(1.334-1.334)^{2}+(1.574-1.574)^{2}}$

$+(1.637-1.637)^{2}+(3.196-3.196)^{2}$

$+(2.205-2.205)^{2}$

$+(2.535-2.535)^{2}+(2.346-2.346)^{2}$

$+(1.805-1.805)^{2}+(1.378-1.378)^{2}$

$D_{11}=0,00$

$D_{12}$

$=\sqrt{(3.244-1.334)^{2}+(3.209-1.574)^{2}}$

$+(3.114-1.637)^{2}+(6.593-3.196)^{2}$

$+(5.600-2.205)^{2}$

$+(5.228-2.535)^{2}+(4.736-2.346)^{2}$

$+(3.555-1.805)^{2}+(2.160-1.378)^{2}$

$D_{12}=6.943,12$

Cluster 2 (C2):

$D_{11}$

$=\sqrt{(1.334-1.468)^{2}+(1.574-1.583)^{2}}$

$+(1.637-1.611)^{2}+(3.196-2.820)^{2}$

$+(2.205-1.861)^{2}$

$+(2.535-2.061)^{2}+(2.346-2.057)^{2}$

$+(1.805-1.388)^{2}+(1.378-890)^{2}$

$D_{11}=999,33$ 


$$
\begin{aligned}
D_{12}=\sqrt{(3.244} & -1.468)^{2}+(3.209-1583)^{2} \\
& +(3.114-1.611)^{2} \\
& +(6.593-2.820)^{2} \\
& +(5.600-1.861)^{2} \\
& +(5.228-2.061)^{2}+(4.736 \\
& -2.057)^{2} \\
& +(3.555-1.388)^{2} \\
& +(2.160-890)^{2} \\
& D_{12}=7.737 .30
\end{aligned}
$$

Cluster 3 (C3):

$D_{11}$

$=\sqrt{(1.334-4.378)^{2}+(1.574-4.347)^{2}}$

$+(1.637-4.021)^{2}+(3.196-7.364)^{2}$

$+(2.205-6.221)^{2}$

$+(2.535-5.788)^{2}+(2.346-4.545)^{2}$

$+(1.805-2.664)^{2}+(1.378-1.481)^{2}$

$$
D_{11}=8.503,26
$$

$D_{12}$

\begin{tabular}{|c|c|c|c|c|c|c|c|c|c|c|c|c|c|}
\hline & & Balita & $\begin{array}{c}\text { Kanak- } \\
\text { Kanak }\end{array}$ & $\begin{array}{c}\text { Remaja } \\
\text { Awal }\end{array}$ & $\begin{array}{c}\text { Remaja } \\
\text { Akhir }\end{array}$ & $\begin{array}{c}\text { Dewasa } \\
\text { Awal }\end{array}$ & $\begin{array}{c}\text { Dewasa } \\
\text { Akhir }\end{array}$ & $\begin{array}{c}\text { Lansia } \\
\text { Awal }\end{array}$ & \begin{tabular}{|l|} 
Lansia \\
Akhir
\end{tabular} & $\begin{array}{c}\text { Manula } \\
\text { Atas }\end{array}$ & \multirow{2}{*}{ C1 } & \multirow[b]{2}{*}{$\mathrm{C2}$} & \multirow[b]{2}{*}{$\mathrm{C3}$} \\
\hline NO & Kecamatan & $\begin{array}{c}\left(\begin{array}{c}0 \\
\text { Thn })\end{array}\right. \\
\end{array}$ & $\begin{array}{c}5-11 \\
\text { Thn) }\end{array}$ & $\begin{array}{c}(12-16 \\
\text { Thn })\end{array}$ & $\begin{array}{c}(17-25 \\
\text { Thn })\end{array}$ & \begin{tabular}{|c|}
$(26-35$ \\
Thn $)$
\end{tabular} & $\begin{array}{c}(36-45 \\
\text { Thn })\end{array}$ & $\begin{array}{c}(46-55 \\
\text { Thn) }\end{array}$ & \begin{tabular}{|c|}
$55-65$ \\
Thn $)$
\end{tabular} & $\begin{array}{c}(65>= \\
\text { Thn })\end{array}$ & & & \\
\hline 1 & $\begin{array}{l}\text { Siantar } \\
\text { Selatan }\end{array}$ & 1.334 & 1.574 & 1.637 & 3.196 & 2.205 & 2.535 & 2.346 & 1.805 & 1.378 & 0,00 & 999,33 & $8.503,26$ \\
\hline 2 & $\begin{array}{l}\text { Siantar } \\
\text { Barat }\end{array}$ & 3.244 & 3.209 & 3.114 & 6.593 & 5.600 & 5.228 & 4.736 & 3.555 & 2.160 & $6.943,12$ & $7.732,30$ & $2.447,19$ \\
\hline 3 & $\begin{array}{l}\text { Siantar } \\
\text { Marimbun }\end{array}$ & 1.468 & 1.583 & 1.611 & 2.820 & 1.861 & 2.061 & 2.057 & 1.388 & 890 & 999,33 & 0,00 & $9.145,03$ \\
\hline 4 & \begin{tabular}{|l|l} 
Siantar \\
Marihat
\end{tabular} & 1.741 & 1.930 & 1.969 & 3.559 & 2.396 & 2.466 & 2.328 & 1.743 & 1.125 & 802,37 & $1.254,66$ & $7.939,82$ \\
\hline 5 & \begin{tabular}{|l} 
Siantar \\
Martoba
\end{tabular} & 4.378 & 4.347 & 4.021 & 7.364 & 6.221 & 5.788 & 4.545 & 2.664 & 1.481 & $8.503,26$ & $9.145,03$ & 0,00 \\
\hline 6 & $\begin{array}{l}\text { Siantar } \\
\text { Sitalasari }\end{array}$ & 2.717 & 2.826 & 2.625 & 5.229 & 4.106 & 4.161 & 3.594 & 2.255 & 1.246 & $4.077,32$ & $4.756,82$ & $4.452,71$ \\
\hline 7 & $\begin{array}{l}\text { Siantar } \\
\text { Timur }\end{array}$ & 3.240 & 3.613 & 3.550 & 9.527 & 5.347 & 5.305 & 4.448 & 3.193 & 2.319 & $8.735,39$ & $9.470,86$ & $2.953,45$ \\
\hline 8 & $\begin{array}{l}\text { Siantar } \\
\text { Utara }\end{array}$ & 4.599 & 4.648 & 4.485 & 9.387 & 7.094 & 6.552 & 5.776 & 3.907 & 2.502 & $11.137,08$ & $11.870,59$ & $3.145,78$ \\
\hline
\end{tabular}

$=\sqrt{(3.244-4.378)^{2}+(3.209-4.347)^{2}}$

$+(3.114-4.021)^{2}+(6.593-7.364)^{2}$

$+(5.600-6.221)^{2}$

$+(5.228-5.788)^{2}+(4.736-4.545)^{2}$

$+(3.555-2.664)^{2}+(2.160-1.481)^{2}$

$$
D_{12}=2.447,19
$$

Berikut Hasil perhitungan selengkapnya pada Tabel 2.

Tabel 2. Hasil Perhitungan Jarak Setiap Kecamatan

\begin{tabular}{|c|c|c|c|c|c|c|c|c|c|c|c|c|c|c|}
\hline & & Balita & \begin{tabular}{|c|} 
Kanak- \\
Kanak
\end{tabular} & $\begin{array}{c}\text { Remaja } \\
\text { Awal }\end{array}$ & $\begin{array}{c}\text { Remaja } \\
\text { Akhir }\end{array}$ & $\begin{array}{c}\text { Dewasa } \\
\text { Awal }\end{array}$ & $\begin{array}{c}\text { Dewasa } \\
\text { Akhir }\end{array}$ & $\begin{array}{c}\text { Lansia } \\
\text { Awal }\end{array}$ & \begin{tabular}{|c|} 
Lansia \\
Akhir
\end{tabular} & $\begin{array}{c}\text { Manula } \\
\text { Atas }\end{array}$ & \multirow[b]{2}{*}{ C1 } & \multirow[b]{2}{*}{$\mathrm{C} 2$} & \multirow{2}{*}{ C3 } & \multirow{2}{*}{ JTK } \\
\hline NO & Kecamatan & \begin{tabular}{|c|}
$\left(\begin{array}{c}(0-5 \\
\text { Thn })\end{array}\right.$ \\
\end{tabular} & \begin{tabular}{|c|}
$\begin{array}{c}(5-11 \\
\text { Thn })\end{array}$ \\
\end{tabular} & $\begin{array}{c}(12-16 \\
\text { Thn })\end{array}$ & $\begin{array}{c}(17-25 \\
\text { Thn })\end{array}$ & $\begin{array}{c}(26-35 \\
\text { Thn })\end{array}$ & \begin{tabular}{|c|}
$(36-45$ \\
Thn $)$
\end{tabular} & \begin{tabular}{|c}
$(46-55$ \\
Thn $)$ \\
\end{tabular} & \begin{tabular}{|c|}
$55-65$ \\
Thn) \\
\end{tabular} & $\begin{array}{c}\left(\begin{array}{c}65 \\
\text { Thn })\end{array}\right. \\
\end{array}$ & & & & \\
\hline 1 & $\begin{array}{l}\text { Siantar } \\
\text { Selatan }\end{array}$ & 1.334 & 1.574 & 1.637 & 3.196 & 2.205 & 2.535 & 2.346 & 1.805 & 1.378 & 0,00 & 999,33 & $8.503,26$ & C1 \\
\hline 2 & $\begin{array}{l}\text { Siantar } \\
\text { Barat }\end{array}$ & 3.244 & 3.209 & 3.114 & 6.593 & 5.600 & 5.228 & 4.736 & 3.555 & 2.160 & $6.943,12$ & $7.732,30$ & $2.447,19$ & $\mathrm{C} 3$ \\
\hline 3 & $\begin{array}{l}\text { Siantar } \\
\text { Marimbun }\end{array}$ & 1.468 & 1.583 & 1.611 & 2.820 & 1.861 & 2.061 & 2.057 & 1.388 & 890 & 999,33 & 0,00 & $9.145,03$ & C2 \\
\hline
\end{tabular}

Setiap record akan menjadi anggota dari suatu cluster yang memiliki jarak terkecil dari pusat clusternya. Misalnya untuk record pertama. jarak terkecil diperoleh pada cluster $\mathrm{C} 1$. maka data pertama akan menjadi anggota dari cluster
C1. Demikian juga untuk data kedua. jarak terkecil ada pada cluster $\mathrm{C} 3$. maka data tersebut akan masuk pada cluster C3. Posisi cluster selengkapnya dapat dilihat pada Tabel 3.

Tabel 3. Posisi Cluster Pada Iterasi Pertama 


\begin{tabular}{|c|c|c|c|c|c|c|c|c|c|c|c|c|c|c|}
\hline 4 & $\begin{array}{l}\text { Siantar } \\
\text { Marihat }\end{array}$ & 1.741 & 1.930 & 1.969 & 3.559 & 2.396 & 2.466 & 2.328 & 1.743 & 1.125 & 802,37 & $1.254,66$ & $7.939,82$ & C1 \\
\hline 5 & \begin{tabular}{|l|} 
Siantar \\
Martoba
\end{tabular} & 4.378 & 4.347 & 4.021 & 7.364 & 6.221 & 5.788 & 4.545 & 2.664 & 1.481 & $8.503,26$ & $9.145,03$ & 0,00 & C3 \\
\hline 6 & $\begin{array}{l}\text { Siantar } \\
\text { Sitalasari }\end{array}$ & 2.717 & 2.826 & 2.625 & 5.229 & 4.106 & 4.161 & 3.594 & 2.255 & 1.246 & $4.077,32$ & $4.756,82$ & $4.452,71$ & C1 \\
\hline 7 & \begin{tabular}{|l|} 
Siantar \\
Timur \\
\end{tabular} & 3.240 & 3.613 & 3.550 & 9.527 & 5.347 & 5.305 & 4.448 & 3.193 & 2.319 & $8.735,39$ & $9.470,86$ & $2.953,45$ & C3 \\
\hline 8 & $\begin{array}{l}\text { Siantar } \\
\text { Utara }\end{array}$ & 4.599 & 4.648 & 4.485 & 9.387 & 7.094 & 6.552 & 5.776 & 3.907 & 2.502 & $11.137,08$ & $11.870,59$ & $3.145,78$ & $\mathbf{C 3}$ \\
\hline
\end{tabular}

Keterangan

JTK : Jarak Terdekat ke Kelompok

Dari Tabel 3 didapat keanggotaan Cluster sebagai berikut:

1. Kelompok $1($ atau $C 1)=\{1,4,6\}$

2. Kelompok $2($ atau $C 2)=\{3\}$

3. Kelompok $3($ atau $C 3)=\{2,5,7,8\}$

Pada tahap ini akan mengitung rasio antara besaran Between Cluster Variation (BCV) dengan Within Cluster Variation (WCV). sebagai berikut:

$$
\begin{aligned}
& B C V=D(C 1 . C 2)+D(C 1 . C 3)+D(C 2 . C 3) \\
& B C V=(999,33-0,00)+(8.503,26-0,00)+( \\
& 9.145,03-0,00) \\
& B C V=18.647,62 \\
& W C V=\sum_{i=1}^{k} \sum_{p \in C i} d\left(p . m_{i}\right)^{2} \\
& W C V=0,00^{2}+2.447,19^{2}+0,00^{2}+802,37^{2}+ \\
& \quad 0,00^{2}+4.077,32^{2}+2.953,45^{2}+3.145,78^{2} \\
& W C V=41.875 .874,00
\end{aligned}
$$

\section{$B C V / W C V=18.647,62 / 41.875 .874,00=$ 0.00044}

Berhubung pada tahapan sebelumnya belum mendapat rasio ini, maka perbandingan rasio belum dapat dilakukan dan proses K-Means clustering. Maka selanjutanya tahap keempat.

\section{Tahap keempat (Iterasi-2)}

Pada tahap ini. perubahan pusat-pusat kelompok akan dilakukan seperti berikut:

a. Untuk Cluster 1, ada 3 data yaitu record ke-1, 4, dan 6. sehingga:

$\mathrm{C}_{11}=(1.334+1.741+2.717) / 3=5.792$

$\mathrm{C}_{12}=(1.574+1.930+2.826) / 3=6.330$

$\mathrm{C}_{13}=(1.637+1.969+2.625) / 3=6.231$

$\mathrm{C}_{14}=(3.196+3.559+5.229) / 3=$ 11.984

$\mathrm{C}_{15}=(2.205+2.396+4.106) / 3=8.707$

$\mathrm{C}_{16}=(2.535+2.466+5.305) / 3=9.162$
$\mathrm{C}_{17}=(2.346+2.328+3.594) / 3=8.268$

$\mathrm{C}_{18}=(1.805+1.743+2.255) / 3=5.803$

$\mathrm{C}_{19}=(1.378+1.125+1.246) / 3=3.749$

Sehingga $C 1=\{5.792,6.330,6.231$,

$11.984,8.707,9.162,8.268,5.803$, $3.749\}$

b. Untuk Cluster 2, ada 1 record, yaitu record ke-3, sehingga:

Sehingga $C 2=\{1.468,1.583,1.611$, $2.820,1.861,2.061,2.057,1.388,890\}$

c. Untuk Cluster 3, ada 4 record, yaitu record ke- 2, 5, 7, dan 8. sehingga:

$\mathrm{C}_{31}=(3.244+4.378+3.240+4.599) / 4$ $=15.461$

$\mathrm{C}_{32}=(3.209+4.347+3.613+4.648) / 4$

$=15.817$

$\mathrm{C}_{33}=(3.114+4.021+3.550+4.485) / 4$

$=15.170$

$\mathrm{C}_{34}=(6.593+7.364+9.527+$

9.387)/4=32.871

$\mathrm{C}_{35}=(5.600+6.221+5.347+7.094) / 4$

$=24.262$

$\mathrm{C}_{36}=(5.228+5.788+5.305+6.552) / 4$

$=22.873$

$\mathrm{C}_{37}=(4.736+4.545+4.448+5.776) / 4$

$=19.505$

$\mathrm{C}_{38}=(3.555+2.664+3.193+3.907) / 4$

$=13.319$

$\mathrm{C}_{39}=(2.160+1.481+2.319+2.502) / 4$

$=8.462$

Sehingga C $3=\{15.461,15.817$,

15.170, 32.871, 24.262, 22.873, 19.505, $13.319,8.462\}$

5. Ulangi tahap ke-3 hingga nilai rasio antara besaran Between Cluster Variation (BCV) dengan Within Cluster Variation (WCV) tidak mengalami penaikan dari nilai rasio sebelumnya. 
Tabel 4. Posisi Cluster Pada Iterasi Kedua

\begin{tabular}{|c|c|c|c|c|c|c|c|c|c|c|c|c|c|c|}
\hline \multirow[b]{2}{*}{ NO } & & Balita & \begin{tabular}{|l|} 
Kanak- \\
Kanak
\end{tabular} & $\begin{array}{c}\text { Remaja } \\
\text { Awal }\end{array}$ & \begin{tabular}{|c|} 
Remaja \\
Akhir
\end{tabular} & $\begin{array}{c}\text { Dewasa } \\
\text { Awal }\end{array}$ & $\begin{array}{c}\text { Dewasa } \\
\text { Akhir }\end{array}$ & $\begin{array}{c}\text { Lansia } \\
\text { Awal }\end{array}$ & $\begin{array}{l}\text { Lansia } \\
\text { Akhir }\end{array}$ & $\begin{array}{c}\text { Manula } \\
\text { Atas }\end{array}$ & \multirow[b]{2}{*}{ C1 } & \multirow[b]{2}{*}{$\mathrm{C} 2$} & \multirow[b]{2}{*}{$\mathrm{C3}$} & \multirow[b]{2}{*}{ JTK } \\
\hline & Kecamatan & $\begin{array}{c}\left(\begin{array}{c}0 \\
\text { - } 5 \\
\text { Thn })\end{array}\right. \\
\end{array}$ & \begin{tabular}{|l|}
$(5-11$ \\
Thn $)$ \\
\end{tabular} & $\begin{array}{c}(12-16 \\
\text { Thn })\end{array}$ & \begin{tabular}{|c}
$(17-25$ \\
Thn $)$
\end{tabular} & $\begin{array}{c}(26-35 \\
\text { Thn })\end{array}$ & $\begin{array}{c}(36-45 \\
\text { Thn })\end{array}$ & $\begin{array}{c}(46- \\
55 \\
\text { Thn) } \\
\end{array}$ & $\begin{array}{c}\text { (55- } \\
65 \\
\text { Thn) } \\
\end{array}$ & $\begin{array}{c}(65>= \\
\text { Thn })\end{array}$ & & & & \\
\hline 1 & $\begin{array}{l}\text { Siantar } \\
\text { Selatan }\end{array}$ & 1.334 & 1.574 & 1.637 & 3.196 & 2.205 & 2.535 & 2.346 & 1.805 & \begin{tabular}{|l|}
1.378 \\
\end{tabular} & $16.843,28$ & 999,33 & $53.324,62$ & C2 \\
\hline 2 & $\begin{array}{l}\text { Siantar } \\
\text { Barat }\end{array}$ & 3.244 & 3.209 & 3.114 & 6.593 & 5.600 & 5.228 & 4.736 & 3.555 & 2.160 & $10.009,73$ & $7.732,30$ & $46.442,31$ & $\mathrm{C} 2$ \\
\hline 3 & \begin{tabular}{|l} 
Siantar \\
Marimbun
\end{tabular} & 1.468 & 1.583 & 1.611 & 2.820 & 1.861 & 2.061 & 2.057 & 1.388 & 890 & $17.609,34$ & 0,00 & $54.077,54$ & C2 \\
\hline 4 & $\begin{array}{l}\begin{array}{l}\text { Siantar } \\
\text { Marihat }\end{array} \\
\end{array}$ & 1.741 & 1.930 & 1.969 & 3.559 & 2.396 & 2.466 & 2.328 & 1.743 & 1.125 & $16.377,84$ & $1.254,66$ & $52.839,37$ & C2 \\
\hline 5 & \begin{tabular}{|l} 
Siantar \\
Martoba
\end{tabular} & 4.378 & 4.347 & 4.021 & 7.364 & 6.221 & 5.788 & 4.545 & 2.664 & 1.481 & $8.864,66$ & $9.145,03$ & $45.085,93$ & C1 \\
\hline 6 & \begin{tabular}{|l} 
Siantar \\
Sitalasari
\end{tabular} & 2.717 & 2.826 & 2.625 & 5.229 & 4.106 & 4.161 & 3.594 & 2.255 & 1.246 & $12.932,35$ & $4.756,82$ & $49.362,73$ & C2 \\
\hline 7 & $\begin{array}{l}\text { Siantar } \\
\text { Timur }\end{array}$ & 3.240 & 3.613 & 3.550 & 9.527 & 5.347 & 5.305 & 4.448 & 3.193 & 2.319 & $8.759,84$ & $9.470,86$ & $44.851,47$ & C1 \\
\hline 8 & $\begin{array}{l}\text { Siantar } \\
\text { Utara }\end{array}$ & 4.599 & 4.648 & 4.485 & 9.387 & 7.094 & 6.552 & 5.776 & 3.907 & 2.502 & $5.900,77$ & $11.870,59$ & $42.214,99$ & C1 \\
\hline
\end{tabular}

Dari Tabel 4 didapat keanggotaan Cluster sebagai berikut:

1. Kelompok $1($ atau $C 1)=\{5,7,8\}$

2. Kelompok $2($ atau $C 2)=\{1,2,3,4,6\}$

3. Kelompok $3($ atau $C 3)=\{\}$

Pada tahap ini akan mengitung rasio antara besaran Between Cluster Variation (BCV) dengan Within Cluster Variation (WCV). sebagai berikut:

$$
\begin{aligned}
B C V & =D(C 1 . C 2)+D(C 1 . C 3)+D(C 2 . C 3) \\
B C V= & (17.609,34-0,00)+(0)+(0) \\
B C V= & 17.609,34 \\
W C V= & \sum_{i=1}^{k} \sum_{p \in C i} d\left(p . m_{i}\right)^{2} \\
W C V= & 999,33^{2}+7.732,30^{2}+0,00^{2}+1.254,66^{2} \\
& +8.864,66^{2}+4.756,82^{2}+8.759,84^{2}+ \\
& 5.900,77^{2} \\
W C V= & 275.124 .634,00
\end{aligned}
$$

\section{$B C V / W C V=17.609,34 / 275.124 .634,00=$ 0.000064}

Karena pada iterasi-2 nilai rasio antara besaran Between Cluster Variation (BCV) dengan Within Cluster Variation (WCV) tidak mengalami penaikan dari nilai rasio sebelumnya (pada iterasi-1). maka iterasi di hentikan dan hasil akhir yang diperoleh ada 2 cluester:

a) Cluster pertama memiliki pusat (4.072, $4.203,4.019,8.759,6.221,5.882$, $4.923,3.255,2.101)$ yang dapat diartikan sebagai kelompok kecamatan dimana jumlah penduduk setiap kategori usia tinggi.

b) Cluster kedua memiliki pusat (2.101, $2.224,2.191,4.279,3.234,3.290$, $3.012,2.149,1.360$ ) yang dapat diartikan sebagai kelompok kecamatan dimana jumlah penduduk setiap kategori usia rendah.

\section{KESIMPULAN}

Dari hasil penelitian, dapat disimpulkan bahwa algoritma klasifikasi $K$-Means dapat digunakan untuk mengelompokkan setiap kecamatan kota Pematangsiantar berdasarkan usia penduduk berdasarkan kategori, yaitu: Balita, Kanak-Kanak, Remaja Awal, Remaja Akhir, Dewasa Awal, Dewasa Akhir, Lansia Awal, Lansia Akhir, Manula Atas. Dari data yang diuji, diperoleh 2 kelompok, yaitu :

1) Kelompok Kecamatan yang jumlah penduduknya tinggi untuk setiap kategori usia adalah Kecamatan siantar Martoba, Siantar Timur, dan Siantar utara dengan pusat Cluster $(4.072$, 4.203, 4.019, 8.759, $6.221,5.882,4.923,3.255,2.101)$.

2) Kelompok Kecamatan yang jumlah penduduknya rendah untuk setiap kategori usia adalah Kecamatan Siantar Selatan, Siantar Barat, Siantar Marimbun, Siantar Marihat, dan Siantar Sitalasari dengan pusat Cluster (2.101, 2.224, 2.191, 4.279, $3.234,3.290,3.012,2.149,1.360)$. 


\section{REFERENSI}

[1] S. Suryadi and D. Irmayani, "Penerapan Metode Clustering K-Means Untuk Pengelompokan Kelulusan Mahasiswa," Inform. J. Ilm. AMIK Labuhan Batu, vol. 6, no. 1, pp. 52-72, 2018.

[2] F. S. Jumeilah, D. Pratama, and S. Penduduk, "MENGGUNAKAN ALGORITMA K-MODES," J. TAM (Technology Accept. Model., vol. 8, no. 2, pp. 85-89, 2017.

[3] W. Purba, S. Tamba, and J. Saragih, "The effect of mining data k-means clustering toward students profile model drop out potential," J. Phys. Conf. Ser., vol. 1007, no. 1, p. 12049, 2018.

[4] S. P. Tamba, M. D. Batubara, W. Purba, M. Sihombing, V. M. Mulia Siregar, and J. Banjarnahor, "Book data grouping in libraries using the k-means clustering method," J. Phys. Conf. Ser., vol. 1230, p. 12074, 2019.

[5] L. Rahmawati, S. W. Sihwi, and E. Suryani, "ANALISA CLUSTERING MENGGUNAKAN METODE KMEANS DAN HIERARCHICAL CLUSTERING ( STUDI KASUS : DOKUMEN SKRIPSI JURUSAN KIMIA, FMIPA , 2 . 3 Term Weighting dengan Term Frequency." 